\title{
Kindred Group as the Prototype of Modern Co- Operative Societies: A Study of Igbo Proverbs
}

\author{
Aloy Nnamdi Obika, PhD; Grace Ifeoma Ikechukwu
}

\author{
Department of English, Madonna University Nigeria, Okija Campus, Anambra State, Nigeria \\ aloyobika@yahoo.com \\ Department of English, Madonna University Nigeria, Okija Campus, Anambra State, Nigeria \\ graceifyikechukwu@gmail.com
}

\begin{abstract}
In 1833, a group of twenty-eight poor but intelligent weavers of Rochdale, England were said to have joined together to source for funds that enabled them to buy goods in bulk, thereby benefiting by cutting off the gain which the retailers would have made from them. This move is said to be the origin of co-operative societies. From their activities, the International Co-operative Alliance coined the seven principles which guide the activities of cooperative societies the world over. However, if these principles are studied and are made to be used in analyzing the activities of some formations even in the prehistoric era, it can be seen that the Rochdale society is not the first organization that utilized the seven principles. In order to prove this fact, the present researchers had to collect some Igbo proverbs that have as part of their content, the umunna (kindred) formation. The content of these proverbs when matched with personal interviews, Internet and hard copy studies of the umunna formation show that indeed, the Rochdale pioneers cannot be said to be the first group that articulated the principles on which cooperative societies are based. As it is in this formation of the Igbo people of south-eastern Nigeria, so it is in many primitive formations.
\end{abstract}

Keywords-Umunna, Co-operative societies, Co-operative principles, Rochdale pioneers, Igbo proverbs.

\section{INTRODUCTION}

In the year 1833, James Smithes discussed with his colleagues what he got from King's Co-operative Magazine. These people were twenty-eight in number, poor but "intelligent weavers of Rochdale [who were] determined to ... improve their lot" (Gartside 1979, p.251). These factory hands realized that there was no way that their life styles could be improved by increasing their earnings. Therefore, they decided to see how they could use their small salaries to buy more and better provisions. In this way, what the retailers would have gotten from them was gained back because of their bulk purchase.

For them to achieve this, they contributed the much they could and in 1844, they rented a room:

... in Toad Lane as a store and from this small beginning a society gradually developed which now numbers its members by thousands and its annual business by hundreds of thousands of pounds, while in place of the humble room is a huge central warehouse with numbers of branch stories (Gartside, 1979, p. 252).
This was how the first co-operative society was established in England. However, it must be pointed out that it was not all that smooth sailing since their first effort collapsed just two years later. It was only later that these twenty-eight pioneers were able to create the prototypical co-operative model with the establishment of their Toad Lane shop in 1844. Today, many co-operative societies scattered all over the world bear the imprint of these Rochdale workers. That can explain why Kimberly A. Zeuli and Robert Cropp (2019) in an online article observe that: "Rochdale became the co-operative beacon for others to follow. It provided the organizational pattern that became the prototype for other co-operatives and spurred on the cooperative movement in Europe and North America" (n.p.). The article further points out that this co-operative model can be seen in such countries like India, Korea and Uganda. That it is so is the evidence of its universal adaptability and diversity.

But who streamlined their activities and channeled the efforts of all co-operative societies were the members of the International Co-operative Alliance. According to the online article of America's Electric Co-operatives (2019), 
no matter the additions, co-operatives "trace the roots of these principles to the first co-operative founded in Rochdale, England in 1844” (n.p.).

But then, it is the International Co-operative Alliance (2016) that formulated the seven co-operative principles that delineate a standard for all these co-operative societies. It is this organization that formulated a standard for evaluating all co-operative societies. In an online article titled "Co-operative identity value and principles," the organization states that: "A co-operative is an autonomous association of persons united voluntarily to meet their common economic, social and cultural needs and aspirations through a jointly owned and democratically controlled enterprise" (n.p.). After this observation, the paper goes on to enumerate and explain the seven identification marks of a standard co-operative society.

However, these principles no matter how eruditely stated and credited to the Rochdale pioneers can be seen in many organizations that started long before 1833. Therefore, these pioneers cannot be said to be too original since before then, England had been embarking on her voyages of discoveries. Who knows whether the people that produced Kings Co-operative Magazine got in contact with such an organization and wrote what inspired James Smithies. But no matter what transpired in those days, Zeuli and Cropp (2019) whose article was earlier cited are unequivocal in stating that:

Groups of individuals around the world and throughout time have worked together in pursuit of common goals. Examples of co-operation of collective action can be traced back to our prehistoric predecessors who recognized the advantages of hunting, gathering and living in groups rather than on their own (n.p.).

It is in view of this that the current researchers are of the view that the umunna kindred groups which exist among the Igbo of south-eastern Nigeria is also guided by the seven co-operative principles formulated by the International Co-operative Alliance. This umunna organization is a body that controls all the male descendants of a particular place. Normally, the members are from different families. As it is defined by Ngozi Ezenagu (2017), in the online edition of African Journals Online:

The umunna can be seen as one of the most important pillars of Igbo society following their allegiance in ensuring the longevity and continuity of family traditions. The leadership role of this group as caretakers of the family traditions, promotes the preservation of Igbo cultural heritage (n.d. p.33).

When the two are compared, the umunna set-up can be seen to be more diversified in its methods of social control than co-operative societies. In this aspect, cooperative societies just like the umunna have the following benefits:

...may include better prices for goods and services, improved services and dependable sources of inputs and markets for outputs. Most co-operatives also realize annual profits, all or part of which are returned to members in proportion to their patronage. (Thus, they are aptly called patronage refunds) (Zeuli and Cropp p.2).

In addition to the above, the umunna organization helps in the social training of the children of the members, spiritual training and other areas that make life worth living in this African society. However, the current researchers will limit their enquiry only on the seven co-operative principles as seen through the prism of Igbo proverbs for in these proverbs are encoded anything worthwhile among this people. If that is the case, one can garner a lot about the umunna social organization of the Igbo people.

\section{Proverbs in the Traditional Igbo Society}

The proverbs of a people are the codified and calcified wisdom of the people. Inside these proverbs can be found all that is dear and useful to them. These proverbs are structured in such a way that they can easily be recalled and applied to different occasions or circumstances. They are so useful that in Igbo land, they are entrusted mainly to the elders who use them to train the young ones.

To Ifeyinwa Cordelia Isidienu (2015), proverbs:

$\ldots$ are the accumulated treasure of Igbo philos ophy throughout the ages. [They] contain the observation, knowledge, wisdom of the forefathers who, not having developed the art of writing were compelled to condense what they would have put down in writing into a short form that could be easily remembered and passed from generation to generation (2016, p.69).

However, it does not contain only the wisdom of the forefathers alone. New proverbs can come up at any time. What it requires is for the saying to contain some cultural and historical wisdom and be so adaptable as to be applied to explain man's interaction with his environment and fellow man. Even in this era with people having the ability to read and write, new proverbs do come up from time to time as far as they contain what can be used to 
evaluate and analyze man's life -- his joyful and sorrowful moments, accomplishments and frustrations, successes and failures and so on.

A thought like this would have motivated Jasper Ahaoma Onuekwusi (2015) in his observation that:

The proverb is about man as he interacts with his fellow man, with objects, animals and plants in his environment. It is a truth derived initially from some observed relationship between man and all phenomena in his environment and indeed between the various elements in the environment and themselves (p.26).

Another scholar, Nkem Okoh (2008) in his study observes that of all the genres of literature, it is in proverbs that the facts of the life of a people and their circumstances are best encapsulated (p. 124). Going further, this scholar states that: "In terms of their subject matter ... proverbs cover virtually every known aspect of life ranging from animals and birds to human activities and affairs, natural phenomena, supernatural beings, abstract or metaphysical ideas" (p.125).

In this way, proverbs can be used to analyze many situations of a people, both their physical and metaphysical existence. Its shortness makes it possible for people to use them easily. This can account for its frequent usages in conversations. In fact, it is so useful that in traditional court sessions, whoever is not capable of making use of them is looked down upon. In such a situation, these proverbs are seen as edicts, by-laws, and whoever fails to make use of them may likely lose the case. It is then understand that the Igbo people define that literary composition as the palm oil with which words are eaten.

From Ruth Finnegan (1998), one can understand that: “... proverbs often imply some general comment on the way people do or should not behave. It is clear that the conveying of a people's experience and expectations can be performed in a particularly effective way through the use of proverbs" (p. 413).

The summary of the whole thing is that proverbs are so important that they can be used to understand, analyze and highlight all social issues. Since some of them descended from the era of the forefathers of the race, one can get the wisdom of those days from these short sayings. In this way, they can serve in studying the umunna organization, its usefulness to the Igbo people and its ability to channel the people's interest towards a co-operative end. It is in view of this that this paper intends to prove that the seven co-operative principles as formulated by the
International Cooperative Alliance had been in an African society before James Smithes was inspired by King's Cooperative Magazine and before the twenty-eight Rochdale weavers went into action in 1833. In this case, one can see the observation of Zeuli and Cropp that co-operative or "collective action can be traced back to our prehistoric predecessors" to be an undiluted truth.

\section{Umunna as an Igbo Social Organization}

Every person in Igbo land belongs to one family or another. Those that belong to the same family refer to themselves as umunne which literarily translated means those from the same mother although they may not be. Such is used to show the intimacy, oneness and love between them. A cluster of these umunne form the umunna, when a cluster of families bearing different surnames are put together.

The importance of this formation which has been helping society in different ways, range from training the younger ones to organizing the members so as to maintain law and order, to disseminating information amongst the members, to organizing members' participation in both sorrowful and joyful occasions and so on. In ways like this, such local formations among the Igbo nation keep the people moving frictionless.

According to Chinyere Ukpokolo (2010):

The villages are segmented into umunna (patrilineage or literarily children of the same father). The umunna is the central and the most influential and the basic socio-political unit of the Igbo indigenous society. It comprises of the descendents in the male line of the founder ancestor by whose name the patrilineage is sometimes called (p.178).

In short, members of different umunne form the umunna. Different umunna form the village and different villages form the town. The essence of these social formations is for the harmonious working of disparate entities.

For Mary Gloria C. Njoku (2019) in an online article:

The principal political organization among the Igbo is the umunna, the agnates, comprising a number of families with a common or related ancestry. A number of umunna comprise the village [which is] also supposed to be linked by a common ancestry (n.p.).

Any critical comparison of this umunna with cooperative societies can easily reveal that the two are geared 
towards uniting different people for them to work harmoniously together, gather what they can and in this way, achieve something worthwhile. That the two mean almost the same thing but differ only in nomenclatures and the levels of societies involved can be seen, although there are differences in the emphasis laid on the points due to differences in societal aims and values. This can be clear when an analysis is made using the seven core principles of the International Co-operative Alliance. But in what follows, much use will be made of Igbo proverbs which for ages have been used to record the people's experiences, culture, history, achievements and failures. Also, oral interviews would be conducted among some people. These coupled with researches in books and the Internet will reveal much about the people and how the umunna formation helps the people to achieve their aims and survive adversities.

This formation has been in existence since time immemorial. The Igbo nation cannot do without it if one is to go by the references made about it in numerous genres of folklore. A study the researchers carried out in one kindred of Nnobi in Idemili South Local Government Area of Anambra State revealed two vital objects owned by the people. These objects can help in guessing the number of years the kindred has lasted. These objects are called onyima and ofo. The former was vital during the era of inter-town wars. The people carried it into the battle fields believing that it would emasculate their enemies, thereby assuring them of victory. The latter is a staff of authority which was used to swear in people for them to carry out certain duties

The usefulness of these two objects has so diminished that they are no longer more important than artifacts in a museum. For one, the British government stopped inter-town wars and for the other, the Christian church placed the latter in the realm of devil worship. That the imperial government and the church silenced them shows the probable years that they have lasted.

The first of the seven principles with which the umunna runs and which can be seen in co-operative societies as recorded by America's Electric Co-operatives (2019) in their online paper is: "Membership in a cooperative is open to all persons who can reasonably use its services and stand willing to accept the responsibilities of membership of race, religion, gender or economic circumstances."

However, to the Igbo people, once anybody is born into that umunna, he is automatically a member. He has to participate in all activities relating to that group, depending on his age but the rule according to Clement Osunwokeh (2015) is that: "The various attributes of membership of umunna very well portray Igbo value of human dignity. One can identify in them respect for fundamental human rights, human liberty and freedom, justice, freewill, personal judgment, etc" (p.4).

It is without any argument that the people are of the view that "A dighi akoro akpiri na ya n'utara bu nwanne -- The gullet is not to be told that he and fufu (pounded cassava, yam, flour, etc,) are kinsmen". The two have some filial relationships which cannot be disputed and that can explain why the fufu ball passes effortlessly down the gullet to the stomach. No matter the type of fufu, whether of yam, flour, cassava and so on, it can slide down the throat as far as there is no bone in it.

Just as membership of a co-operative society is open to all so far as the individual will "accept the responsibilities of membership of race, religion, gender or economic circumstances," so also can anybody born into any umunna comply with whatever the group wants to do. After all, "Nke-m-di-iche bu ajo afo -- Mine-is-different is a bad name". Therefore, when nobody wants to be referred to as Nke-m-di-iche, everybody will accept the responsibilities of membership no matter what it entails. Only rarely are some people "ostracized from the community for breaking certain taboos ... committing certain sins considered grave in the community or disobeying important laws or orders of the community" (Osunwokeh, 2015, p.4).

When such happens, let it be seen that nothing is permanent in existence just as some may opt out of any cooperative society when they feel that the gain is no longer there. Such happened in Rochdale when just after two years of its existence, it failed, leaving only the twenty-eight pioneers to continue in the struggle.

The second of the seven principles is stated thus:

Cooperatives are democratic organizations controlled by their members who actively participate in setting policies and making decisions. Elected representatives... are elected from among the membership and are accountable to the membership. In primary co-operatives, members have equal rights (one member, one vote).

Democratic process is by no means alien to the Igbo people. According to them, "Nwa muo emegbuna nwa mmadu, ma nwa mmadu emegbuna nwa mиo - Let not the child of the spirit victimize the human child but let not the human child victimize that of the spirit." Everybody should 
be taken and treated fairly well. In this case, everybody's interest is well taken care of.

In P. O. Opone's (2013) work where he cites Onwuegogwu, it is on record that: "Within the umunna system, political power was diffused and highly democratized. The umunna system 'encouraged political dialogue, equality, communalism and egalitarianism at all levels or lineage segments ..." (p.59).

From all ramifications, whatever transaction that occurs will be supported by the majority - not necessarily by everybody. But in spite of that, not all the decisions are said to be oha-zulu-kwu (the-people-collectively-s aid). This can account for the online statement of Ekwe Nche Organization:

During the Izu (meeting), the umunna does not usually strive for unanimous agreement on the is sues. Rather, they seek to establish an acceptable majority. And once this majority has been established, it becomes the consensus and all opposition ceases as everyone is expected to stand with the group. This is why Ndigbo [Igbo people] have the saying; "Onye umunna ya gburu adi agba mei" (Whoeveris killed by his umunna does not shed any blood) (n.p.)

To show the power in having the majority vote, the people coined a proverb which says: "Umunna bu ikeUmunna is strength". This proverb can also be rendered in other ways as "Igwe bu ike -- The majority is strength". The majority or the umunna stands behind the person that is being supported and can be available when needed in "setting policies and making decisions".

Therefore, one can hear that "Otu onye anaghi emeri umunna ya - One person alone cannot subdue the members of his umunna". This is because the collective will is greater than the will of just one person. Even if the person is the elected chairman, there is nothing he can achieve without the support of those that elected him, for the control comes from them. If he fails in his duties, he is immediately dethroned if the majority wants it so. Herein lies part of western idea which controls the democracy being referred to by the International Co-operation Alliance and Igbo Democracy.

In further differentiation of the two types of democracy, Ekwu Nche Organization states that:

It is important to emphasize that unlike what happens in Western democracy where money and affluence seem to be determining characteristics for elections to representative offices, in Igbo culture, the value or quality of a person is not determined in dollar and cents or naira and kobo. It is determined by the individual performance on the assigned task. Therefore, money and material possession do not constitute supreme parameters in selecting an individual to represent his umunna or village (n.p.).

This stand is supported by one Igbo proverb which states that 'Otu onye anaghi akari umunna ya -- One person cannot be greater than his umunna. Umunna which was earlier stated to be strength cannot be easily subdued by one person.

Concerning the qualifications that can enable one to be the leader of umunna, a lot is taken into consideration nowadays. Western incursion into the Igbo terrain has changed a lot of things. Initially, the eldest man used to be the leader of the umunna. Then, the Igbo firmly believed that elders must be fair in all their dealings and must always tell the truth and be associated with all life-affirming virtues. In those days as can be seen in the online paper of the Ekwe Nche Organization:

... leadership of the umunna is vested in the eldest male in the umunna who is called okpara, opara, onye ishi, diokpa, etc. [depending on the dialect]. The diokpa keeps the custody of the ofo, the sacred stick which symbolizes [something] in all decisions and rulings. The authority of the diokpa is not imbued with dictatorial power as he must consult with all the family and possibly obtain consensus on the issue at hand before making a ruling (n.p.).

The above situation is now obtainable only in few places. But in most areas today, what is considered is the worth of the individual. Is he honest and hard working? Does he have the interest of the village at heart and can he go an extra mile to elevate the status of the people? But no matter the issues at stake, the current researchers have not seen or heard of any person canvassing or campaigning to be elected the leader of the umunna. What happens is that any time that there would be a change of leadership, the members would nominate those that they think could do well. Either the persons accept or reject the nomination. Those who finally accept will be voted for by people raising their hands. He who has the highest number of votes will be the leader. Here, as it is in the second principle, "members have equal rights (one member, one vote)".

Concerning the statement in the second principles that "elected representatives ... are elected from among the membership and are accountable to the membership," 
among the umunna, it is never possible that an outsider will hold any elective position. That situation has never occurred before. For one thing, any person outside the umunna is a total stranger. For the other, the person can never be at the scene where the voting is taking place. To the people, "Okuko o na-akpanye n' afo ewu? Does the fowl eat for the food to enter into the stomach of the goat? In other words, orderliness should always be in the happenings of the umunna.

The summary so far is that refined democracy is today being practiced among the umunna irrespective of the state of this country where money is the determinant in every is sue. Money politics has not seeped in to corrupt the system. Money is the canker worm that has corrupted a lot of things in Nigeria. Concerning the political scene, the Ekwe Nche Organization in the same online paper already cited, notes that "Those who invest heavily in order to clinch an elective post must amass or embezzle heavily in order to recoup their expenditures. This, in other words, breeds corruption" as it is in Nigerian national politics and leadership (n.p.).

The third of the principles states that: "Members contribute equitably, and democratically control the capital of their co-operative. At least, part of that capital remains the common property of the co-operative."

Among the umunna, there is what is called $u t u$ umunna (umunna levy). Any person who is of age must contribute. School boys and those who are incapacitated are exempted. The money is used for diverse purposes -- like during funeral ceremonies in order to console the bereaved, helping out some families who are facing adversities, and so on. One of the present researchers was in his village, where he attended the umunna meeting. The chairman enumerated two vital issues that were challenging the organization. One of them was that the umunna would contribute a large sum of money toward the building of the village hall which for some time was stalled after the completion of the second floor. Also, in the market place, the umunna was allocated a portion of land for the construction of stalls.

In this way, the umunna has sources of revenue and at the same time, has places that demand for expenditure. Like modern co-operative societies "members contribute equitably ...." Also, because of the sort of persons the group elected to lead them, embezzlement is minimized for the purse is democratically controlled.

Among the umunna, it is a thing of joke if somebody is said to be incapable of paying his own levy. To the relatives of the person, it is a thing of shame for it can be seen as a kind of wickedness on their part. Others help their relatives who are faced with adverse conditions. In their own case, they neglect their brother and in this way, forgetting or even neglecting the proverb of the people which is: "Umunna na-eme ka obi sie madu ike - The umunna helps to embolden somebody's heart." Under this condition, instead of emboldening their brother's heart who is in adversity, they want him to die. Some may ask: Does it mean that the entire family cannot put resources together and help their brother? Are you sure that they are not targeting his piece of hand? In ways like this, unsavory stories may originate.

But why will such stories not originate when it is the saying of the people that "Onye Chukwu goziri kwesiri ime umunna ya obi uto -- Whoever God blesses ought to make glad the hearts of the members of the umunna (kindred)".

Since the Igbo nation practices extended family system, there is no person who exists without relatives. These relatives have unwittingly annoyed the members of umunna in their failure to help their kinsman who is in distress. But the truth is that such a situation has never been heard to have occurred within living memory. That can explain why it is said: Oko kobo anu ohia, o gaa chie ahu ya n'osisi ma okoba mmadu, o gaa mmadu ibe yo a koo ya -- When an animal is itching, it goes and rubs its body on a tree but if it is a human being that is itching he goes to another human being to scratch it for him. But to whom will the person go to? Definitely to his direct relatives or friends or to the members of his umunna. Why them? This is because, Obara siri ike -- Blood is strong.

The fourth principle is rendered as follows:

Co-operatives are autonomous self-help organizations controlled by their members. If they enter into agreements with other organizations including governments or raise capital from external sources, they do so on terms that ensure democratic control as well as their unique identity.

In this, one can see from the discourse so far that just as the co-operative societies are autonomous self-help organizations, so are different umunna organizations. None is an appendage of another except that of the village which it is a part of. In short, if one, in the course of discussing with another refers to the other's village as being a vassal of one's umunna, it will be violently resisted. A likely reply will be: How? Obu umunna m suchaa utala, umunna gi ekunyere anyi ofe? Does it mean that after my umunna has pounded fufu, your umunna will give us soup? To say that 
one umunna is subservient to another is an insult that may result into a fight or sharp exchange of words, if care is not taken.

As for entering into agreements with other organizations especially with the village or town, nothing will make the people to deviate from their democratic setup. After all, will the umunna instead of "Ime omenani, $e$ emee omenenu? -- Acting out what is practiced on the land, practice what is in the sky?"

No leader of any umunna will, in any agreement with external bodies, fail to "ensure democratic control." If he fails to do so, he will surely be misunderstood by his own people who will now start suspecting him of duplicity. If such were to happen, one can easily see a member who will say: “Ndi be anyi, umunna anyi bu n' isi ukpolo -- Our people, our umunna is carrying a load on a bare head (without a pad). Another may observe: "Ewu ataa umunna anyi igu n' isi --Goat has eaten the palm frond on the head of our umunna." Both proverbs depict utmost betrayal and lack of trustworthy people.

In the case of raising money or going into agreement with the government, such a situation may not arise because the umunna can, in rare cases, interact with the town leadership thereby bypassing the village level and the ward, where the latter is available since "Umunna agaghi ahapu isi aka gbaa uriom -- The umunna will not bypass the thumb in order to snap its fingers". The meaning is that there are certain situations which must be obtained for orderliness and success to reign.

The fifth principle goes like this: "Education and training for members, elected representatives ... CEOs, employees help them effectively contribute to the development of their co-operatives."

While co-operative societies educate, train and inform the members about the things that will push them along, the umunna people do so on the things that will help them. The methods are different. In the course of investigating this, one of the researchers of this paper was in Umuobi, Eziehulu, Awuda Nnobi which is in Idemili South Local Government Area of Anambra State. One man, Anthony Agudosi revealed to him how the young ones in some decades before, were monitored and punished when they went astray. Any erring child would be taken to the house of one Felix Nwachukwu Okagbue where he would be laid on a table for scores of strokes of sticks to be administered on his buttocks.

Also, it is still the work of the elders to be making themselves available to the youngsters whom they teach the ways of the people using tales, myths, legends, proverbs and so on. The essence is to make them not only to be abreast of the norms of their people but be successful in life.

To the people: Umunna nwezue aku, nsogbu agaghi adi -- When every member of umunna is well to do, there will not be any problem. This is born out of the experience that an untrained person is a problem and a nuisance to society. In short, such a person is a social menace. From such people, you get such social misfits like pilferers or robbers, ritualists, envious people who can go as far as poisoning others and so on.

For the members of the umunna to curtail such excesses, they help others to stand on their feet. The following is from a paper presented by Damian Mbaegbu and Ehijiele Ekienabor (2018) who quote Onwuejeogwu's observation that:

A successful entrepreneur picks up a nephew or a young cousin and puts him under internship in his own line of business for some years until he is able to freelance on his own with the seed or endowment capital the "master" will give him. While on his own, the young fellow also tries to mentor another relation and the group develops entrepreneurially (p.54).

Most members of umunna want it so that their place will develop. According to one proverb, "Umunna nwezue aku, o na-ada di ayi di ayi -- When every member of umunna is affluent, there will be the sounding of the greeting: My eminent colleague, my eminent colleague." In other words, camaraderie exists where none is a pauper and everybody is affluent. Under such a situation, members of other umunna will respect them. Such will auger well for the people.

That this is the traditional desire among Igbo people can be seen in the work of Chinua Achebe (1976) where the entire town of Umuofia has to cough out some money in order to send their son, Obi Okonkwo to England for him to study law. The novel states that:

Six or seven years ago, Umuofians abroad had formed their union with the aim of collecting money to send some of their brighter young men to study in England. They taxed themselves mercilessly. The first scholarship under this scheme was awarded to Obi Okonkwo five years ago almost to the day (p.41).

When he got there, instead of studying law, he studied the English language. On returning to the country, he got a job in the Federal Civil Service Commission and 
landed into a law suit when he was caught taking bribe. Yet, his people never despair. They have to tax themselves again. As the president of the union points out, "a kinsman in trouble had to be saved, not blamed; anger against a brother was felt in the flesh, not in the bone" (1996, p.40/41).

In summary, the members of the umunna join together to train the younger ones both morally and entrepreneurially. This is because to the Igbo man, "Nwa abughi nwa otu onye; nwa bu nwa oha nile -- The child is not just the child of one person; the child belongs to everybody". Therefore, if the extended family cannot train a child, the umunna comes in or even the town can take up the responsibility as in the case of Obi Okonkwo above.

The sixth principle of co-operatives as itemized by the International Co-operative Alliance (2016) is as follows: "By working together through local, national, regional and international co-operatives improve services, bolster local economists and deal more effectively with social and community needs."

The umunna has to do with local folks in the countryside. So, their working like co-operatives through national, regional and international co-operatives is cancelled because there is nothing like national, regional and international umunna. One umunna can only work together with another umunna or the village itself. That is how Umuobi Eziehulu teamed up with Umuokpala Eziehulu in order to construct a village hall which is a three-storey building. These mentioned kindred have market stalls and other establishments as their possessions.

Not working together has never been part of the experiences of the people. To them, Umunna nyukoo amiri onu, o gboo ufufu -- When the members of the umunna urinate at a particular spot, the urine foams. This means that anything collectively or jointly embarked on has a marvelous result and can be easily accomplished. Under that condition, their working together "improves services, bolsters local economists and [can] deal more effectively with social and community needs."

For the people to cancel the idea of individual endevours and to show that such cannot result in a tremendous achievement, here is another proverb: $O b u$ mgbasa mgbasa mere n' agwo enweghi umunna -- It is separation that makes the snakes not to have a kindred group. The Igbo know and enjoy their different kindred groups. If snakes as dangerous as they are have such a formation, who can dare enter into any bush where they are? They can achieve much but with their separating themselves from each other, a person can finish cutting a bush where there are many snakes without their attacking him. Kill one snake, the others cannot challenge him. Therefore, the umunna kindred group helps to foster unity and satisfies "social and community needs."

This idea of unity that promotes tremendous achievements can be seen in Osunwoke's study of the umunna solidarity on Igbo land. After looking at a popular proverb: Aka nri kwoo aka ekpe, aka ekpe akwoo aka nri, ha abua adi ocha, he goes on to translate it. According to him: "A popular Igbo adage, "When the right hand washes the left hand and the left hand washes the right hand, the two will be clean," expresses fully the Igbo value of cooperation as a moral principle of dignified life" (2015, p.5).

The snakes lack this knowledge and that explains why men kill them and lord it over them. These snakes which can be used to represent those who quarrel amongst themselves and try to accomplish everything individually do not know that: Onye umunna ya kwu n'azu, egwu anaghi atu ya -- Whoever that is backed by his umunna is never afraid. But why should such a person be afraid when solidily behind him are all his people each contributing what he knows best? Under this condition, the umunna, since almost all the people are involved, will have more improved services, more bolstering of local economists and better handling of social and community needs than the best co-operative society in existence.

Finally, the seventh principle of co-operation says that: "Co-operatives work for the sustainable development of their communities through policies supported by the membership." Among the umunna, the prime issue is that all must garner resources so as to move their place forward. Already, it has been pointed out how the people were helping to take the younger ones, train them for these younger ones to learn their line of business. It used to be more in practice before now when most people want their children to acquire university degrees. What the people do is that whoever sees anybody whose business seems to be booming is to approach the owner for him to train his child for him. The approached person can hardly refuse to take the child except when there is no vacancy in his establishment, for as the people say in one of their proverbs: Onye huru igwurube ma ghara ikpo umunna ya, ndi bara ohia, obu onye nweh ha? -- Whoever sees a swarm of locusts and does not tell his umunna, who owns the locusts that at the end enter into the forest (after he has collected all that he could). 
For the people to keep on improving, it is on record according to Victor C. Uchendu (1965) that: "The ити-nna collects taxes, helps in recovering levies as and when imposed by the government and towns, settles problems among themselves, reprimands and

forestalls behaviour that are inimical to the well being of kindred" (p.56). In this way, there is less acrimony among the members thereby creating less conflicting situations. Under this condition, there is progress.

As for settling conflicts among them, it has been witnessed severally that the umunna helps the young man by showing solidarity on the day he goes to marry a wife. If at a point it becomes clear that he cannot financially do all that is required, any member of the umunna can help out, voluntarily.

As it is commonly known to everybody -Akpataghi aku bu n'akpatalu, umunna richaa. Literarily translated, it can be rendered thus: It is being unable to acquire wealth that results into its being finished by the kindred. The meaning is that one should help out his kindred if he can afford it. But if in the process of one's helping others and his wealth finishes, it means that one's wealth initially was small. In all, what these efforts amount to is that the community is being developed and these moves are supported by the members of the kindred.

That such is the case can be seen in the publication of Ifeyinwa Cordelia Isidienu (2016) where she states that: " ... any male child of the umunna that is ready to erect a house will be allotted an agreed portion of land. He will immediately start his building with the help and encouragements of other members of the family" (p.4/5). That the umunna is referred to as a family in this citation shows the conviviality and oneness obtained among the group. One of the current researchers was in the house of Obi of Oduda, Nnewichi, Nnewi some years ago in the house of his grandmother. The old woman had no surviving male child and her roof was leaking. The umunna had to source money amongst themselves and some, who could not contribute financially had to put in manual contributions for the old widow to have a house with no leaking roof. In this way, the umunna like "co-operatives work for the sustainable development of their communities through polices supported by the membership."

\section{CONCLUSION}

The first co-operative society was traced to the efforts of twenty-eight poor and intelligent weavers of Rochdale, England. From there, many societies originated.
As time went on, the International Co-operative Alliance collected data and after some analysis, came up with a set of principles that lie behind successful co-operatives. That is what the world today knows about co-operative societies. Praises are then showered on those twenty-eight weavers for forming an organization that was hitherto inexistent.

However, Zeuli and Cropp are of a contrary view that these weavers created something new. Instead of associating the formation of such a noble venture to the Rochdale workers, these scholars are of the view that prehistoric people did such a thing and so should be given the credit. It is in view of such an assertion that the current researchers looked at the Igbo formation, umunna which consists of the male members of a particular place. Such people can trace their descent to a particular person whose name the organization sometimes bears.

On analyzing the activities of such a kindred formation using Igbo proverbs since these proverbs are one of the few records of the activities of people whose only records of the past before being exposed to Western civilization are in oral narratives, it was discovered that the entire seven principles on which co-operative societies operate can be seen in Igbo kindred formation, umunna. It has existed from time immemorial and has been adjusting gradually to the forces of modernism but not to the extent that it has been distorted out of its original emphasis.

Therefore, the uтипna kindred formation is one of those prehistoric formations to be credited as the first cooperative societies or one of those societies that predated the Rochdale Co-operative Society of England.

\section{REFERENCES}

[1] Achebe, Chinua. (1970). No longer at ease. London: Heinemann Educational Books Ltd.

[2] America's Electric Co-operatives. (2019). Understanding the seven co-operative principles. [online] Available: https://www.electric.coop/seven-cooperative principles.

[3] Ekwe Nche Organization. (n.d.). Leadership in Igbo society: analysis, challenges and solutions. [online] Available: www.biafraland.com/leadership-intro.htm.

[4] Ezenagu, Ngozi. (2017). Leadership styles in the management of Igbo cultural heritage in preEuropean era. [online] Available:https.//www.ajol.info/index .php/org/article/view Five/6/153/150714. pp.22-45.

[5] Finnegan, Ruth. (1998). Oral literature in Africa. Nariobi: Oxford University Press.

[6] Gartside, L. (1979). English for business studies. Plymouth: Macdonald and Evans Ltd. 
[7] International Cooperative Alliance. (2017). Co-operative Identity, Values and Principles. [online] Available: https://www.ca.coop/en/cooperatives/identity.

[8] Isidienu, Ifey inwa Cordelia. (2015). Philosophy of Igbo proverbs: the logic, ethics and esthetics in Igbo culture. Journal of Religion and Human Relations 8(1). [online]. Available: https://www.ajol/.info/index.php/irhr/arti cle/view/149078.

[9] Mbaegbu, Damian and Ekienabor, Ehijiele. (2018). Driver of entrepreneurship among the Igbos of the south eastern geopolitical zone of Nigeria. International Journal of Advanced Studies in Economics and Public Management 6(1). pp. 4962.

[10] Njoku, Mary Gloria C., Anieke, Christian C., Okafor, Richard C., Isiwu, Prisca and Adeyinka, Babajide Gideon. (2019). Traditional methods of promoting peace in southeast Nigeria. [online]. Available: www.christiananike.net/speech/phpdf.

[11] Ogbukagu, IK. N. T. (1997). Traditional Igbo beliefs and practices: a study on the culture and people of AdaziNnukwu. Owerri: Novelty Industrial Enterprises Ltd.

[12] Okoh, Nkem. (2008). Preface to oral literature. Onitsha: Africana First Publisher Limited.

[13] Onuekwusi, Jasper Ahaoma. (2015). Fundamentals of African oral literature (revised edition). Owerri: Alphabet Nigeria Publishers.

[14] Opone, P. O. (2012). Traditional socio political organization of the Enuani Igbo of south central Nigeria. Stud Tribes Tribals 10(1). pp. 57-64.

[15] Osunwokeh, Clement I. (2015). Human dignity stance of umunna solidarity in Igbo traditional society: a challenge to African Christianity. Journal of Scientific Research and Reports 8(2). pp. 1-11.

[16] Ukpokolo, Chinyere. (2010). Gender, space and power in the indigenous Igbo socio-political organization. Pakistan Journal of Social Sciences 7(2). pp.177-186.

[17] Zeuli, Kimberly A. and Cropp, Robert. (2019). Co-operative: principles and practices in the $21^{\text {st }}$ century. [online] Available: uwex.edu/assets/pdfs/A/457PDF. 